\title{
The Influence of Inflation Level, Exchange Rate and Gross Domestic Product on Foreign Direct Investment in the ASEAN Countries on 2007 - 2018
}

\author{
John FoEh, Ni Kadek Suryani, and Shakti Silpama
}

\begin{abstract}
This research aims to determine the effect of the inflation rate, exchange rate and gross domestic product to the foreign direct investment in the ASEAN countries in periods of 2007-2016. The object of this research is the foreign direct investment in 11 countries of ASEAN region such as; Brunei Darussalam, Philippines, Indonesia, Cambodia Laos, Malaysia, Myanmar, Singapore, Thailand, Timor-Leste and Vietnam. The data used are secondary data with analysis by a panel data regression model using with an estimated model of random effect which were processed by Eviews tools version 10 . The results of this study indicate that simultaneously the inflation rate, exchange rate, and gross domestic product have a very significant effect to the foreign direct investment. Partially, the inflation rate has a significant negative effect on foreign direct investment, while the exchange rate has a significant positive effect on foreign direct investment. The further analysis showed that the gross domestic product has no significant effect on foreign direct investment.
\end{abstract}

Keywords - Inflation Rate, Exchange Rate, Gross Domestic Product, Foreign Direct Investment.

\section{INTRODUCTION}

At the end of 2008, the world economy was confronted with problems that have an impact on the financial crisis and caused the collapse of world economic stability. One of the major impacts of the crisis was the announcement of a freeze on several securities by one of France's largest banks, BNP Paribas, which is bound to high-risk housing loans in the United States (subprime mortgages). This triggered the instability of financial markets that spread throughout the world. The peak of this crisis which had a huge impact on the world was when it was announced the bankruptcy of the largest investment bank of the United States, Lehman Brothers, which led to the growing intensity of this crisis.

Published on May 22, 2020.

John FoEh, IPU, Gunadarma University Faculty of Economics, Indonesia. (corresponding e-mail : johnfoeh@gmail.com)

Ni Kadek Suryani, MM, Mahasaraswati University, Indonesia. (e-mail : suryani.staal@gmail.com)

Shakti Silpama, SE, Gunadarma University Faculty of Economics,

Jakarta Indonesia. (e-mail: silpamas@gmail.com )
The worst economic condition felt by the entire world was in 2009, where the world economic growth rate was in a negative position with a value of -1.378 percent (World Bank, 2018) [20]. This condition has an impact on all countries in the world without exception the countries in the ASEAN region.

The impact of the crisis has resulted in a drop in share prices, bankruptcy of financial institutions and also an impact on the decline in currency exchange rates and the banking sector experiencing liquidity difficulties in countries in the ASEAN region. In the aftermath of the crisis, countries in the ASEAN region carried out a restructuring program, where this program was useful in being able to restore and improve economic structures to achieve improved and stable economic growth [15]. Economic conditions that began to improve in 2010 can occur because countries in the ASEAN region are pushing and creating direct international trade relations with other countries in the region which have resulted in the formation of a connected and strong regional trade network, so it is resistant to crisis shocks from time after time. Based on the matter eressed by the OECD (Organization for Economic Co-operation \& Development) that the growth of countries in the ASEAN region is expected to remain good for the next few years, it is a continuation of trade that has increased strongly over the impact of high domestic consumption and infrastructure improvement plans and investment policies in each country (OECD, 2018).

Improved infrastructure and investment policies in each country make ASEAN the main economic power in Asia and the driver of world economic growth with a total nominal GDP of $\$ 2.31$ trillion. Diancou [5], in her research explained that Southeast Asia will continue to attract investors because of competitive advantage, this is influenced by economic reforms that are continuously implemented by countries in the ASEAN region, which is focused on improving the investment environment of countries in the ASEAN region. The European Union is the largest investor group for countries in the ASEAN region by contributing more than 22 percent of the total inflow of foreign direct investment from 2000 to 2016. This was followed by Japan, the United States and China as countries 
participating in allocating investment for countries in the ASEAN region. According to the Japan Bank for International Cooperation (JBIC), around 56\% of Japanese companies intend to expand business in the ASEAN region over the next three years, especially the Vietnam, Indonesia and Thailand markets [16]. The level of foreign direct investment for countries in the ASEAN region in 2016 reached $\$ 96$ billion, this is influenced by several factors that make this region attractive for foreign investors to invest, including rapid economic growth, the ASEAN region which more integrated, a significantly improved investment environment and an increase in the number of ASEAN companies that are more mature in investing and expanding business units in the ASEAN region (ASEAN Investment Report, 2017).

The role of foreign direct investment for developing countries, especially countries in the ASEAN region, has a significant impact on economic growth, this is because developing countries generally have problems with low productivity and limited capital. Foreign direct investment is a key element in the rapidly developing international economic integration today, foreign direct investment provides the means to create direct, stable and long-lasting relations between related countries so as to create good economic growth.

The global economy that continues to evolve has a lot of influence on the flow of foreign direct investment funds and the impact on allocating the flow of funds used for economic development in several developing countries. The relationship between foreign direct investment and economic growth has a significant impact, where there is a positive influence from the entry of foreign investment in supporting economic growth in a country. Research Kaur et al., [9] found that GDP per capita and foreign investment were integrated in the long run. Freckleton et al., [6] in their research stated that foreign direct investment has a significant influence on both short-term and long-term economic growth for developing and developed countries.

Based on the description above, the purpose of this study is to find out whether inflation, exchange rates and gross domestic product affect foreign direct investment in countries in the ASEAN region for the period 2007-2018.

\section{LITERATURE REVIEW}

\section{A. Foreign Direct Investment}

Foreign direct investment (FDI) pursuant to Act No.1 of 1967 No.11 of 1970 concerning foreign investment is direct foreign investment made according to or based on the provisions of the Act in Indonesia, in the sense that the capital owner directly bears the risk of the investment. Another understanding defines foreign direct investment as investment that involves long-term relationships and reflects the eternal interests and control of a resident entity in the country of origin (direct foreign investor or parent company) in the host country. This happens with the purchase of significant physical assets or ownership (shares) from a company in another country to get a measure of management control [1].

\section{B. Inflation}

According to Bank Indonesia, inflation is simply defined as rising prices in general and continuously. An increase in the price of one or two items alone cannot be called inflation unless the increase is widespread (or results in a price increase) in other goods. Inflation can also be interpreted as a decrease in the value of a currency against the value of goods and services in general.

\section{Exchange Rates}

Exchange rates is the price of a currency against other foreign currencies. Exchange rates allow the balance of demand and offer against currencies in foreign and foreign currencies. The exchange rate of a currency is determined by the demand-request supply of the currency. If the demand for a currency increases, as the offer remains or decreases, the exchange rate of the currency will rise. If the offer of a currency increases, while demand is steadily or declining, then the exchange rate will continue to fall [13].

\section{Gross Domestic Product}

Gross Domestic Product (GDP) is defined as the market value of all goods and services produced in a country over a certain period of time [7]. Another opinion states that GDP is the total output produced within a country's borders in one year. GDP measures the value of goods and services produced in the territory of a country without differentiating citizenship at any given time period [2].

\section{E. Framework of Study}

This research was conducted to find out how the influence of inflation, exchange rates and gross domestic product on foreign direct investment in countries in the ASEAN region for the period 2007-2016.

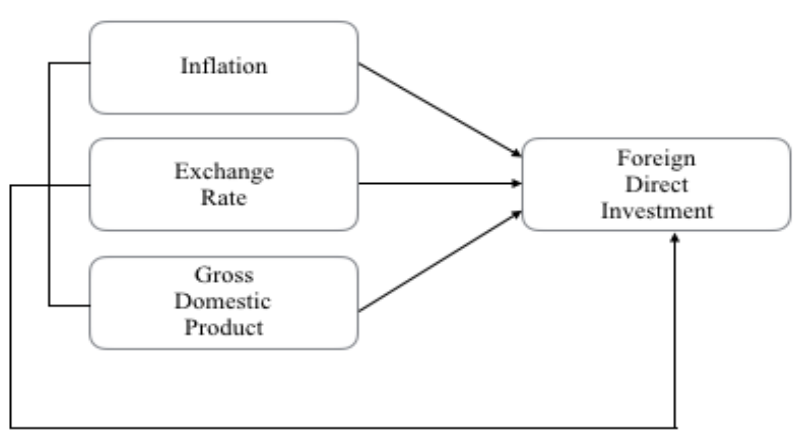

Figure 1. Framework of Study

\section{RESEARCH METHODOLOGY}

This research uses descriptive method with quantitative approach, where descriptive method is used to make systematic, factual and accurate description or description of facts related to research problems. The type of data used in 
this study is secondary data. Secondary data used in this study are historical data from 11 countries in the ASEAN region during the period 2007 to 2016 . The data used in this study include several macroeconomic indicators that can encourage inflows of foreign direct investment in countries in the ASEAN region. The macroeconomic indicators include inflation, exchange rates and gross domestic product. The research data was obtained from webside of the United Nations Conference on Trade and Development (UNCTAD) and website of the World Bank.

The data source used in this study is panel data which is a combination of time series data and data cross section. This study combines data time series over a period of 10 years from 2007 to 2016, and observations cross section in 11 countries in the ASEAN region, namely Brunei Darussalam, the Philippines, Indonesia, Cambodia Laos, Malaysia, Myanmar, Singapore, Thailand, Timor Leste and Vietnam.

The method of data analysis conducted in this research model is panel data regression analysis with the stages of testing carried out including the determination of panel data estimation models, classic assumption tests, panel data regression analysis and significance tests.

\section{RESULTS AND DISCUSSION}

\section{A. Determination Panel Data Model Estimation}

TABLE 1 : DETERMINAN TEST PANEN DATA MODEL ESTIMATION

\begin{tabular}{|l|l|l|}
\hline \multicolumn{1}{|c|}{ Test } & \multicolumn{1}{|c|}{ Results } & Conclusions \\
\hline $\begin{array}{l}\text { Chow Test } \\
\mathrm{H}_{0}: \text { Common Effect Model } \\
\mathrm{H}_{1}: \text { Fixed Effect Model }\end{array}$ & $\begin{array}{l}\text { F-statistic }=51.61 \\
\mathrm{df}=10 ; 96(1,931)\end{array}$ & $\begin{array}{l}\mathrm{H}_{0} \text { rejected, } \\
\mathrm{H}_{1} \text { accepted. }\end{array}$ \\
\hline $\begin{array}{l}\text { Hausman Test } \\
\mathrm{H}_{0}: \text { Random Effect Model } \\
\mathrm{H}_{1}: \text { Fixed Effect Model }\end{array}$ & $\begin{array}{l}\text { Probability value }= \\
\text { Mixel }\end{array}$ & $\begin{array}{l}\mathrm{H}_{0} \text { accepted, } \\
\mathrm{H}_{1} \text { rejected. }\end{array}$ \\
\hline Source: Data processed & & \\
\hline
\end{tabular}

Source: Data processed

Based on the test results in Table 1. shows the results that when the Chow test was performed, the F-count result was 51.61 while the F-table of numerator 10 and denumerator 96 at $\alpha$ : 5\% was 1,931. So from the above hypothesis can be concluded that $\mathrm{H}_{0}$ is rejected because the F-count is greater than F-table $(51.61>1931)$, so the model used in this study is the fixed effect model. Furthermore, to find out what approach is most appropriate for use in this study, it is necessary to test the fixed effect model with the random effect model using the Hausman Test. Based on the Hausman test results in Table 1. the results obtained probability values greater than $0.05(0.6204>0.05)$ indicate that the conditions for accepting of $\mathrm{H}_{0}$. Where $\mathrm{H}_{0}$ indicates that the random effect model is better than the fixed effect model, so it can be concluded that the right approach model used in this study is a random effect model.

\section{B. Classical Assumptions \\ Multicollinearity Test}

TABLE 2: MULTICOLLINEARITY TEST RESULTS

\begin{tabular}{|c|c|c|c|c|}
\hline & FDI & INF & RATE & GDP \\
\hline FDI & 1 & -0.21 & 0.18 & -0.16 \\
\hline INF & -0.21 & 1 & 0.20 & 0.38 \\
\hline RATE & 0.18 & 0.20 & 1 & 0.24 \\
\hline PDB & -0.16 & 0.38 & 0.24 & 1 \\
\hline
\end{tabular}

Source: Data processed

According multicollinearity test results in Table 2 using an independent variable partial result that there is no multicollinearity problem with the independent variables used. That is because the value of the correlation matrix smaller than the Rule of thumb which is 0.85 .

\section{Heteroscedasticity Test}

TABLE 3: HETEROSCEDASTICITY TEST RESULT

\begin{tabular}{|l|c|c|c|c|}
\hline Variable & Coefficient & Std. Error & t-Statistic & Prob. \\
\hline C & 963.831 & 746.318 & 1.8106 & 0.0730 \\
\hline INF & -31.045 & 36.625 & 0.8544 & 0.3948 \\
\hline RATE & 92.807 & 111.735 & 0.6094 & 0.5435 \\
\hline GDP & -167.244 & 143.974 & -1.5241 & 0.1305 \\
\hline
\end{tabular}

Source: Data processed

According Heteroscedasticity Test Results in Table 3. using test Glejser was done by adjusting the white standard errors to avoid the data from the existence of heteroscedasticity, it is found that all variables have probability values above 0.05 , which means that it can be concluded that the variables in this study are free from heteroscedasticity. In the approach model random effect, there are advantages that can eliminate heteroscedasticity so that the assumption of non-heteroskedasticity has been fulfilled.

\section{Panel Data Regression Analysis}

Panel data is a combination of time series data and cross section data. The panel data regression model approach used is the random effect model. This model will estimate panel data where interruption variables may be interconnected between time and between individuals. In the random effect model, the intercept differences are accommodated by the error terms of each object studied [17]. The form of the equation is formulated as follows:

$\mathrm{LN}(\mathrm{FDI})=\alpha+\beta_{1} \mathrm{INF}_{\text {it }}+\beta 2 \mathrm{KURS}_{\text {it }}+\beta_{3} \mathrm{GDP}_{\text {it }}+\mathrm{w}$ it Where:

$\alpha \quad$ : Constants

$\beta_{1}-\beta_{3} \quad$ : Regression coefficient 
$\mathrm{W}$ it : component error

Based on Table 4. Can be obtained the following regression formula:

$\mathrm{LN}(\mathrm{FDI})=6.630573-0.048935 \mathrm{INF}$ it +0.223823

Exchange rate it +0.032955 GDP $_{\text {it }}$

TABLE 4: RESULT OF REGRESSION ANALYSIS PANEL DATA

\begin{tabular}{|l|l|l|l|}
\hline Variable & Coefficient & t-Statistic & Prob. \\
\hline C & 6.630573 & 7.876755 & 0.0000 \\
\hline INF? & -0.048935 & -2.731889 & 0.0074 \\
\hline $\begin{array}{l}\text { EXCHANGE } \\
\text { RATES? }\end{array}$ & 0.223823 & 2.379579 & 0.0191 \\
\hline GDP? & 0.032955 & 0.974920 & 0.3318 \\
\hline R-square & 0.139220 & & \\
\hline $\begin{array}{l}\text { Adjusted R- } \\
\text { square }\end{array}$ & 0.114858 & & \\
\hline F-statistic & 5.714694 & & \\
\hline Prob (F-statistic) & 0.001153 & & \\
\hline \multicolumn{2}{|l|}{ Source: Data processed }
\end{tabular}

\section{E. Simultaneous Test (F-Test)}

TABLE 5: SIMULTANEOUS TEST RESULTS

\begin{tabular}{|c|c|}
\hline F-statistic & 5.714694 \\
\hline Prob (F-statistic) & 0.001153 \\
\hline
\end{tabular}

Based on the results in Table 5. Simultaneous test results on the panel data regression model with aapproach random effect model, the probability value (F-statistic) of significance was 0.001153 , it was pointed out that the probability value F-statistic $<0.05$. Then it can be concluded that the variables of inflation, exchange rate, and gross domestic product have a significant effect on foreign direct investment simultaneously or together.

\section{F. Partial Test ( $t$ Test)}

TABLE 6: PARTIAL REST RESULTS

\begin{tabular}{|c|c|c|}
\hline Variable & Coefficient & Prob. \\
\hline C & 6.630573 & 0.0000 \\
\hline INF? & -0.048935 & 0.0074 \\
\hline EXCHANGE? & 0.223823 & 0.0191 \\
\hline GDP? & 0.032955 & 0.3318 \\
\hline
\end{tabular}

Source: Data processed

Based on the partial test results in Table 6., it can be explained as follows:

1. The effect of the inflation rate (INF) on foreign direct investment (FDI) shows a probability value smaller than $0.05(0.0074<0.05)$ with a regression coefficient amounting to -0.048935 . This shows that there is a significant negative effect that occurs between the inflation rate (INF) with foreign direct investment (FDI).

2. The effect of the exchange rate (KURS) on foreign direct investment (FDI) shows a probability value smaller than
$0.05(0.0191<0.05)$ with a regression coefficient of 0.223823 . This shows that there is a significant positive effect that occurs between the exchange rate (KURS) with foreign direct investment (FDI).

3. The influence of gross domestic product (GDP) on foreign direct investment (FDI) shows a probability value greater than $0.05(0.3318>0.05)$ with a regression coefficient of 0.032955 . This shows that there is no significant effect that occurs between gross domestic product (GDP) with foreign direct investment (FDI).

\section{G. Determination Coefficient}

TABLE 7: DETERMINATION COEFFICIENT TEST RESULTS

\begin{tabular}{|c|c|}
\hline R-square & 0.139220 \\
\hline Adjusted R-square & 0.114858 \\
\hline
\end{tabular}

Source: Data processed

According to Table 7. The coefficient of determination results, obtained R-square value of 0.139220 . These results indicate that foreign direct investment can be explained by this research model based on the dependent variable used by $14.2 \%$ while the remaining $85.8 \%$ can be influenced or explained by other variables not included in this research model.

\section{DISCUSSION}

Based on the results of the inflation rate variable regression analysis based on Table 4. note the coefficient value is negative at -0.048935 , with a significance value smaller than the level of significance set $(0.0074<0.05)$. This shows that the inflation rate has a significant negative effect on foreign direct investment. This shows that if the inflation conditions experience a significant increase will have an impact on the weakening of the investment value, and vice versa if the inflation rate weakens or tends to decline, the investment value will increase and attract investors. The high level of inflation in a country will have an impact on the decline of investors interest to invest their capital due to high investment costs, otherwise if the inflation rate is low the investment costs will also be low so as to increase investor interest in investing. This is in line with the theory put forward by Kasmir [8], the inflation rate is negatively correlated to investment. The results of this study are in line with the results of research by Pratiwi et al [14], which shows that inflation has a significant negative effect on foreign investment.

The results of the regression analysis of exchange rate variables based on Table 4 . known positive coefficient value of 0.223823 , with a significance value smaller than the level of significance set $(0.0191<0.05)$. This shows that the exchange rate has a significant positive effect on foreign direct investment, so it can be interpreted that the higher the 
value of a country's currency, it will have an impact on increasing the value of investment, in this case the positive impact of a stronger exchange rate is to make prices for imported raw materials declining so that it will have an impact on high product competitiveness that can benefit investors and the country, conversely when the exchange rate decreases it will have an impact on rising commodity prices for imports, rising production costs resulting in high prices of goods, local product competitiveness weakens due there is a dependence on imported raw materials and the high outflow of foreign capital whose impact will have an effect on rising interest rates and inflation. This will give rise to negative sentiment for investors on the perception of investment risk towards the allocated investment fund. The results of this study are in line with research conducted by Meita Sari and Baskara [11], finding that the exchange rate has a significant positive effect on foreign direct investment.

The results of regression analysis of gross domestic product variables based on Table 4. known positive coefficient value of 0.032955 , with a significance value greater than the level of significance set $(0.3318>0.05)$. This shows that gross domestic product does not significantly influence foreign direct investment. The increasing growth of gross domestic product in a country will have a positive impact on the country's economic development, and can provide added value to the country in increasing the flow of investment funds from local and foreign investors. The relatively high increase in gross domestic product growth will also have an impact on weakening inflows from foreign direct investment, which is caused by relatively good economic conditions or a tendency to strengthen which will release a country's dependence on high donors from other countries. Chan et al [4], in their research found that the short and long term growth of gross domestic product directly affects on foreign direct investment.

Based on the description of the test results of the coefficient of determination in Table 7. note the results Rsquare of 0.139220 . These results indicate that foreign direct investment can be explained by this research model based on the dependent variable used by $14.2 \%$, while the rest of $85.8 \%$ can be influenced or explained by other variables not included in this research model. This happens because countries in the ASEAN region have different economic conditions that make a variety of indicators that can be used in making an assessment for investors. Investors not only determine whether a country is worthy to be made a destination country in investing based on inflation, exchange rates and gross domestic product variables. In general, investors tend to determine the assessment based on other indicators such as the availability of raw materials, cheap labor costs, the availability of markets, and the availability of supporting infrastructure and other indicators.

\section{CONCLUSION}

Based on the results of the research described, conclusions can be drawn about the influence of the inflation rate, the exchange rate and gross domestic product on foreign direct investment in the ASEAN countries as follows:

1. Inflation rate, exchange rate and gross domestic product have a simultaneous effect on foreign direct investment.

2. The inflation rate has a significant negative effect on foreign direct investment.

3. The exchange rate has a significant positive effect on foreign direct investment.

4. Gross domestic product does not significantly influence foreign direct investment.

\section{FUTURE RESEARCH}

Limitations that might affect this study include the period of observation that can be updated with the addition of the latest data, other macroeconomic variables that can contribute better results than the variables used in this study, it is hoped that future research will obtain more actual and comprehensive results so that it can be used as reference material for a more in-depth study of similar research topics.

\section{REFERENCES}

[1] Ahmed, Shahid. 2013. Foreign Direct Investment, Trade and Economic Growth Challenges and Opportunities, New Delhi: Routledge

[2] Arif, Dodi. 2014. Effect of gross domestic product, money supply, inflation and bi rate on the composite stock price index in Indonesia for the period 2007 - 2013. Journal of Business Economics, Volume 19 No. 3

[3] ASEAN. 2018. ASEAN Investment Report 2018. http://asean.org/?static__ post $=$ asean-investment-report-2017.

[4] Chan, LMW, Keqiang Hou, Xing Li, and Dean C. Mountain. 2014. Foreign direct investment and its determinants: A regional panel causality analysis. The Quarterly Review of Economics and Finance, Vol. 54 pp. 579 - 589. www.elsevier.com

[5] Diancu, Laura. 2013. The foreign direct investments in South-East Asia in the context of the 1997 and 2007 crises. 2n World Conference on Business, Economics and Management -WCBEM 2013. www.sciencedirect.com

[6] Freckleton, M., Allan Wright, and Roland Craigwell. 2012. Economic growth, foreign direct investment and corruption in developed and developing countries, Journal of Economic Studies, Vol. 39 Issue 6 pp.639-652. http://dx.doi.org/ 10.1108 / 01443581211274593. www.emeraldinsight.com

[7] Jochumzen, P. 2010. Essentials of Macroeconomics. Denmark: Ventus Publishing ApS

[8] Kasmir. 2010. Banking Management. Third Edition. Sixth Printing. Jakarta: PT. Raja Grafindo Persada

[9] Kaur, Manpreet., Surendra S. Yadav, and Vinayshil Gautam. 2013 A bivariate causality link between foreign direct investment and economic growth. Journal of International Trade Law and Policy, $\begin{array}{llllllll}\text { Vol. } & 12 & \text { Issue } & 1 & \text { pp. } & 68 & - & 79 .\end{array}$ http://dx.doi.org/10.1108/14770021311312502. www.emeraldinsight.com

[11] Meita Sari, Agung Ayu R. Gusti., and Gde Kajeng Baskara. 2018. Effects of Economic Growth, Interest Rates, and Exchange Rates on 
Foreign Direct Investment in Indonesia. Eud Management EJournal, Vol. 7, No. 7.

[12] OECD. 2018. Economic Outlook for Southeast Asia, China and India 2018: Fostering Growth Through Digitalisation. Paris: OECD Publishing. http://dx.doi.org/9789264286184-en

[13] Prasetyo, DA, and A. Darmawan. 2017. Influence of inflation risk, interest rate risk, exchange rate risk and leverage on profitability (a study of food and beverage sub sector companies listed on the Indonesia Stock Exchange in 2012-2016). Journal of Business Administration (JAB), Vol. 50 No. 3. business administration. studentjournal.ub.ac.id

[14] Pratiwi, Nabilla, M., Moch Dzulkirom AR., and Devi F. Azizah. 2015. The Influence of Inflation, SBI Interest Rates, and Exchange Rates on Foreign Investment and Economic Growth in Indonesia (2004 to 2013). Journal of Business Administration (JAB), Vol. 26, No. 2. business administration. studentjournal. ub.ac.id

[15] Setiawan, SRD 2017. BI: Post-Financial Crisis, ASEAN is now Rising and Strong. https://ekonomi.kompas.com/read/2017/04/28/151506626/bi.pascakrisis.finance. asean.kini.bangkit.dan.kuat.

[16] Tieying, Ma. 2016. Why Japan's Investing More in Southeast Asia. https: // www. dbsinsights.com/asias-growth-story/japans-investingsoutheast-asia.

[17] Tri Basuki, Agus. 2016. Regression Analysis in Economic \& Business Research: Equipped with SPSS \& Eviews Applications. Ed. 1, Cet. 1. Jakarta: Rajawali Press

[18] Unctad.org

[19] aseanstats.org

[20] Databank.worldbank.org

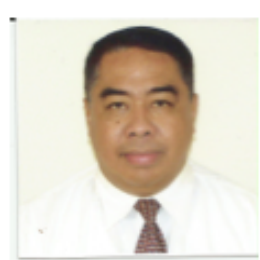

Prof. Dr. Ir. John FoEh, IPU. Senior Lecturer, Professor of Resource Economics in Faculty of Economics, Gunadarma University Jakarta Indonesia. Doctor in Forestry Economics from ENSAI-INPL France in 1990. University Lecturer since 1982.

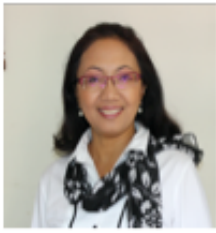

Dr. Ni Kadek Suryani, SE, SIKom, MM. Doctor in Human Resources Management and currently to be a lecture in Postgraduate Program, Mahasaraswati University, Denpasar Bali Indonesia. She has a background as a practitioner, researcher and management book writer.

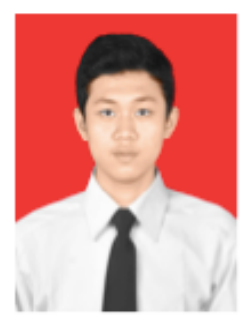

Shakti Silpama, SE. Date of birth Bekas 2 November 1996, Graduate from faculty of Economics, Gunadarma University Jakarta Indonesia in 2018. From 2016 to 2019 work as assistant in macroeconomics laboratory, Gunadarma University and currently he is working as a private company dealing with economics and finance. 